\title{
Primary Soil Formation and Dynamics of the Evolutional Transformation of Minerals under Action of Living Matter
}

\author{
Mukhomorov V., Anikina L., Zvereva T. \\ Universita degli Studi di Napoli "Federico II" \\ Via Cintia, I-80126, Napoli, ITALY \\ vmukhomorov@mail.ru
}

\begin{abstract}
We present the results of a comprehensive study of soil-forming processes under the influence of a long-term and end to end ( 7.5 years; twenty three vegetations) cultivating of the plants on initially lifeless mineral substrates (crushed granite, zeolite) under controlled conditions. The data were obtained under regulated conditions. It was shown that the higher plants (tomato, spring wheat) can actively participate in the pedogenesis process. We analyzed the evolutionary dynamics of the accumulation of organic matter and the dynamics of the biotic community. The result of the biogenic weathering minerals is decomposition of the rock, washing-out of the mineral elements, transformation of the minerals, formation of a secondary minerals and melkozem. We give consideration of the evolutionary dynamics of the chemical composition of plant tissues (roots, stems, leaves and reproductive organs). It was analyzed the percentage of the plant tissues the following chemical elements: $\mathrm{P}, \mathrm{S}, \mathrm{Cl}, \mathrm{Ca}, \mathrm{Mg}, \mathrm{Na}, \mathrm{K}, \mathrm{Fe}, \mathrm{Si}, \mathrm{Al}, \mathrm{Mn}, \mathrm{Zn}$. It was used the information approach for a quantitative analysis of the interrelation dynamics of changes in the chemical composition of the mineral substrates and chemical composition of plant tissues. The chemical composition of the mineral substrate evolutionary changes so that it is close to the information content of the plant root system. Studies processes of accumulation and transformation of the organic matter in the mineral substrate have shown that in a very short period of time under conditions of intense year-round cultivation of plants in the mineral substrates occur an intensive their enrichment by organic substance.
\end{abstract}

\section{Keywords}

Dynamics; Mineral substrate; Soil formation; Tomato plants; Spring wheat; Chemical elements; Weathering; Granite crushed stone; Zeolite; Controlled system; Vegetation; Information function; Organic matter; Biotic community; Soil like body; Living matter.

\section{Academic Discipline And Sub-Discipline}

Agricultural Science; Soil Science; Primary Soil Formation; Evolution.

\section{SABJECT CLASSIFICATION}

\section{Biology Subject Classification \\ TYPE (METHOD/APPROACH)}

Experimental; Applied Statistics, Information Theory

\section{INTRODUCTION}

Vernadsky V.I. [1] pointed out the close connection between the chemical composition of plants and the composition of earth's crust. In this paper we present the results of studying the dynamics of mineral substrate transformation and modification of the chemical composition of plant tissues (roots, stems, leaves and reproductive organs), obtained under conditions of soil-forming process simulation. These processes are accompanied by initial soil formation. Soil formation can significantly change its character under the influence of the mere time. Polynov B.B. [2] paid attention on this little-known problem of primary soil formation. Thereupon, it is represent the interest the modeling of the evolution transformation of the initially lifeless a mineral substrate under the action of a higher plants This type research gives an opportunity both to identify the dynamics of the accumulation of the organic matter in the mineral substrate and to trace the development of the biotic community. In addition, such study allows us to trace the dynamics of the chemical composition variations of plant tissues at the interaction of plant root systems with the mineral substrate. There is very little published information dealing with this subject. This comprehensive experiment also allows us to study both the dynamics of the mineral substrate transformation and the processes of primary soil formation under the influence of living substance.

In this article we present the results of research on the intensive, uninterrupted and prolonged ( 7.5 years; the twenty three continuous vegetations) under cultivation of tomato and spring wheat on initially lifeless 
granulated mineral substrates (crushed granite, zeolite) under controlled conditions. Controlled agroecosystem provides researchers with a unique opportunity to study the early stages of soil formation and dynamics of the transformation of the inert mineral rocks into soil-like body under the influence of living substance. In this paper, we also discuss the results of experiments on the bioavailability dynamics, and dynamics changes of the chemical elements content ( $P, S, C l, C a, M g, N a, K, F e, S i, A l, M n, Z n)$ in plant tissues. Little is known at present about transfer of chemical elements from minerals to the plant tissues under long term operation of substrates. It is of interest the study of minerals modification. To present day the dynamics of the minerals transformation have been little studied. We find out the intensity and nature of the impact of living substance and the products of its vital activity on the mineral composition of substrate. We also report the results of mineralogical studies that demonstrate the profound changes of mineral substrates. The dynamics of this process is poorly understood in the scientific literature. In addition we make demonstrate the interrelation of the chemical composition degradation of the mineral substrate with the dynamics of change in the content of the chemical elements in plant tissues.

\section{PROBLEM FORMULATION}

Objects of our comprehensive research were basic components of a controlled agro-ecosystem i.e., higher plants, the biotic community of root zone, the forming organic matter, and initially lifeless the mineral substrates. We cultivated the spring wheat (variety Siete Cerros) and the tomato plants (variety Ottawa-60) on the mineral substrates (crushed granite and crushed stone zeolite) under controlled conditions. The starting substrates are inert mineral bodies which are situated inactive state (practically lifeless). As soilforming material, granite is widespread on the earth's surface. We used the crushed granite which included $(98 \%)$ particles of size $5-9 \mathrm{~mm}$ with the specific surface area $0.6 \mathrm{~m}^{2}$ per gram and the polydispersity index of 57\%. Quartz, feldspar, mica, amphibole, and chlorite (minerals listed in diminution order of their content) are the main mineral components of the granite rubble. The products of hypergene alteration of the granite i.e., the clay minerals (kaolinite, hydromica) are present at small quantities. X-ray analysis demonstrated that the starting crushed granite for the most part consists of quartz and feldspar. The zeolite rubble (the majority of the particles have a size of 3-7 mm) consists of clinoptilolite with small amounts of quartz and feldspar. Rubble has high the hydrophilic dispersivity and well-defined microporosity of the molecular sieve. For zeolite the polydispersity index is equal to $67.25 \%$.

The length of daylight is equal to 16 hours a day. Vegetative period is equal to 75 days. The air temperature during the day was $24-26 \mathrm{C}$, and the night of $22-24 \mathrm{C}$, respectively. The relative humidity is equal to $60-65 \%$. One liter of the nutrient solution contains the following components: calcium nitrate $(1 \mathrm{~g})$, potassium nitrate $(0.25 \mathrm{~g})$, potassium phosphate monosubstituted $(0.25 \mathrm{~g})$, magnesium sulphate $(0.25 \mathrm{~g})$. The composition of the nutrient solution is not changed during the experiment.

We grew spring wheat and tomato plants in the crushed granite for twenty-three vegetations. Besides we cultivated tomatoes on the zeolite during the eleven vegetations. After that we cultivated the spring wheat up to twenty third vegetation cycle on the same mineral substrate. This crop rotation was attributable to the fact that at the eleventh growing season we have seen a significant decrease in plant productivity [3]. Details of the experiment are discussed in detail in references [4].

\section{PROBLEM SOLUTION}

Lately, there is considerable interest in the study of the role played by $S i$ and $A /$ in plant life. We note the significant fluctuations of chemical elements content in plant tissues under conditions of multi-vegetation experiment. For example, the phosphorus content in tomato roots changes from $15.8 \%$ (after the thirteenth vegetation) to $27.2 \%$ (after the twentythird vegetation). At the same time, the calcium content is changed from $41.2 \%$ (after the first vegetation) to $22.5 \%$ (after the twenty-first vegetation). Similar variations we have observed for other chemical elements. These changes can be caused by synergism and antagonism of the chemical elements in plant tissues [5] and the evolutionary transformation of the mineral substrate.

Our studies have shown that increasing the number of vegetation cycles is accompanied by the active formation of manifold the organic substances into the mineral substrate. The mineral substrates are enriched with the organic matter in the form of primary production of the autotrophic organisms. The experiment demonstrated that the most intense accumulation of the total carbon in the substrate is observed during the first seven vegetations. Content of the total organic matter significantly increased into granite rubble after the twenty-third of vegetation cycles. (Fig.1). When we cultivated tomatoes total carbon content increased in five times, while cultivating wheat leads to increased by six times. In Figure $1 \mathrm{~A}$ are shown dynamics of total organic matter. The total nitrogen content is also increased (Fig.1B). For example, the content of total nitrogen in the mineral substrate was $2 \mathrm{mg}$ per $100 \mathrm{gram}$ of substrate after the first vegetation (variant 
tomato plants). After the twenty-third vegetation this content is increased more than fifteen times: $31.7 \mathrm{mg}$ per $100 \mathrm{gram}$ of substrate. We observed a similar increase in the content of the organic matter under growing spring wheat. It is known that the humic substances contain the various metal cations as well as phosphorus, silicon, sulfur, and chlorine thus providing plants with nutrients.

An important characteristic of the primary soil-forming process is the formation of a multi-component composition of the organic matter. We monitored the dynamics of changes in the biochemical composition of formation of the organic matter, including cellulose, hemicellulose, alkaline-soluble and alcohol-benzene fractions, and nonhydrolyzed residue, as well as the amount of its water-soluble part in the nutrient solution. In addition, we analyzed the dynamics of the species composition and amount of microorganisms (bacteria consuming mineral nitrogen, bacteria consuming organic nitrogen, spore-forming bacteria, cellulose-fermenting bacteria, fungi, and actinomycetes) in mineral substrate. After each growing season, we studied the chemical composition of the formed organic material which includes cellulose, the hemicelluloses, alkali-soluble and alcohol-benzene fractions, the non-hydrolysable residue, and the water-soluble fraction. We observed a monotonic increase in the relative content of the alkali soluble fraction when reducing the fraction of cellulose, the alcoholbenzene fraction (after the eighth growing season), and the hemicellulose. Such a change in the chemical composition of organic matter clearly demonstrates the continuing intensification of the processes of the humification of organic matter by the end of the experiment.

Our researches of the evolutional transformation processes of the organic matter showed similarity these processes with the formation of the humic substances in the natural settings. "Youthfulness" of formed humic acids is also confirmed by their IR spectra. Our spectrograms demonstrate the closeness of the molecular structure of the humic acids with the structure of the humic acids of the natural soil [6]. Controlled agroecosystem has the restricted volume of the rootinhabited zone. This leads to a higher density of living substance per unit of specific surface area in comparison with natural soils. For small volumes of the root zone the plant roots penetrate into the mineral particles substrate. That is, almost all the particles of mineral substrate are situated in the contact with roots. Therefore, the interaction of the living matter with mineral substrates is higher or comparable with the natural soil. The experiment showed that the result is a high rate of change in the physicochemical and biological properties of the mineral substrate.

The experimental data have allowed us to analyze the dynamics of bioavailability [2] of chemical elements from mineral substrates under condition of microevolution pedogenesis. In our experience, the number of vegetation is the time factor. The evolution of relative content of chemical elements (especially $\mathrm{Si}, \mathrm{Al}, \mathrm{Fe}, \mathrm{Mn}, \mathrm{Na}$ ) in plant tissues reflects the dynamics of transformation and weathering of the mineral substrates under the influence of the plant roots, microflora and organic matter

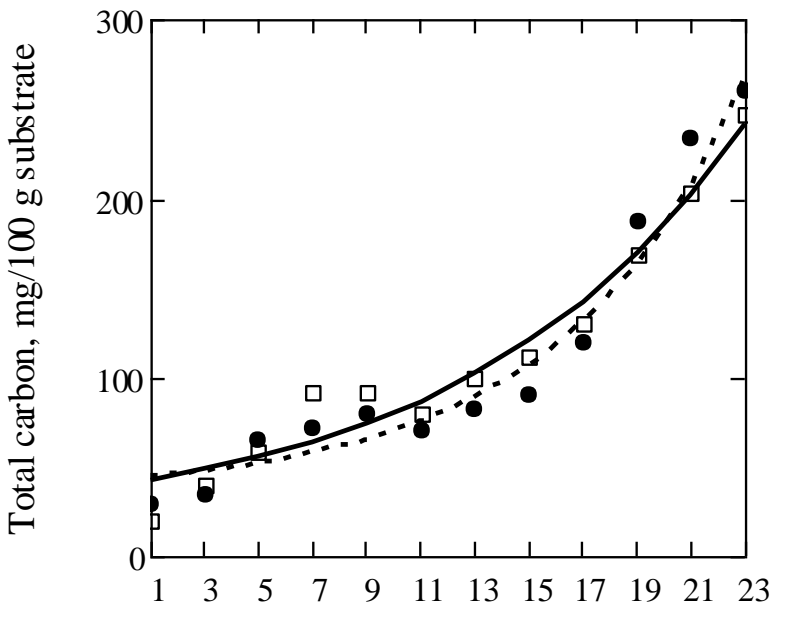

Vegetation

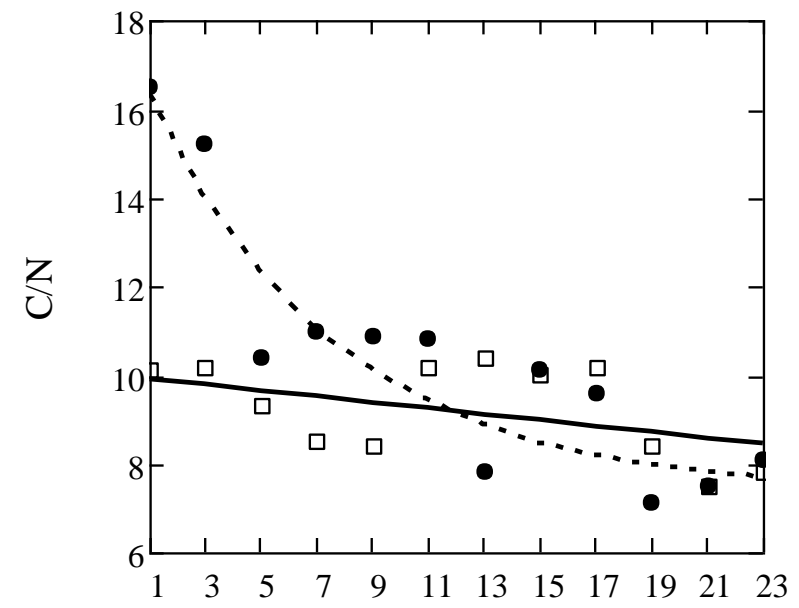

Vegetation

Fig. 1: The dynamics of total carbon content $(A)$ and dynamics of the relationship $(C / M)$ of total carbon to nitrogen (B) in mineral substrate. Crushed granite. Tomato. $\longrightarrow$ the trend, $\square-$ the experiment. Spring wheat. - - the trend, $\bullet-$ the experiment. 
This closeness is determined by the appearance of the maxima of absorption bands which typical for natural soils. However, we found distinctions. In comparison with the natural humic acids, new formed humic acids have much more pronounced absorption in range of the wave number $3000-3550 \mathrm{~cm}^{-1}$. This absorption is due to stretching vibrations of hydroxyl (phenolic and alcohol) groups related to each other by hydrogen bonds. We observed an absorption maximum in the range of wave numbers $2850-2985 \mathrm{~cm}^{-1}$ which indicate a high content of peripheral chains of the aliphatic type with molecular groups $-\mathrm{CH}_{2}$ and $-\mathrm{CH}_{3}$. This is confirmed by observed bands of absorption at the region of wave numbers $1465-1440,1390 \mathrm{~cm}^{-1}$ (deformation vibrations of the chemical bond $-\mathrm{CH}$ at the molecular groups $-\mathrm{CH}_{2}$ and $-\mathrm{CH}_{3}$ ) [6-9]. If that is done, an important component of primary soil formation, namely the accumulation of the organic matter and formation of the humic substances.

According to V.I.Vernadsky [2], the microorganisms are one of the most powerful agents that are involved in the transformation of the lithosphere. The existence in the initial minerals of the micro-pores, micro-cracks and microcapillaries promotes the development of the microbial communities [10]. The increase of the time of operation the mineral substrate promotes the growth the number of microorganisms from different taxonomic groups (bacteria, fungi, actinomycetes), as well as increasing diversity of the biotic community. After the first growing season of spring wheat and tomato plants we found that the number of microorganisms is equal to 4.2-5.1 thousand per gram of dry substrate. The further operation of the mineral substrate has led to an increase in the number of microorganisms. By the end of the experiment the number of microorganisms had increased under the influence wheat and tomato to 255 and 80 thousand per gram of dry substrate, respectively. This obviously increases the phytopathogenic potential of the mineral substrate. As the time of operation of the mineral substrates is increased then increases relative fractions of fungi and actinomycetes. The latter circumstances are directly related to an increase in mass of the organic matter in the mineral substrate. That is, as in natural conditions, there is a relationship between the dynamics of quantitative and qualitative composition of the multi-component organic matter of the mineral substrate and by the development of a multi-component biotic community.

We can represent quantify the dynamics of diversity of the multi-component organic matter and the biotic community using information function $H$ (Fig.2). For a quantitative description of the dynamics of multi-component system (chemical composition of the organic matter and numerical or species compositions of the biotic community) it is convenient to use an integral index i.e., the Shannon information function [11]. Information theory methods allow approach to study of the temporal organization between coupled subsystems from qualitatively new positions. This approach to an analysis of experimental results belongs to the class of statistical methods of reducing the sample size and singling out the most common informative factors. Information function of the finite ensemble of objects can be written in nat (or nit) units in the following way:

$$
H=\sum_{i=1}^{n} p_{i} \ln p_{i}, \text { in units nat (or nit) }
$$

under additional conditions $1 \geq p_{i} \geq 0$ and $\sum_{i=1}^{n} p_{i}=1$. Where $n$ is a discrete number of object-features of the set, which determine the space of possible values of $p_{i}$. Information function (1) is an integral index of the state of the multicomponent system. The values of $p_{i}$ determine the share of the th element in the entire collection of the set of elements (e.g., its percentage content or relative content of organic matter fractions of the mineral substrate), that is $p_{i}$ assigns the number of realizations or possible ways out. Actually, to calculate the specific number $p_{i}$, we use A.N.Kolmogorov's combinatorial approach [12] for a collection of $n$ elements entering into this set with normalized mass $p_{i}$. Here $p_{i}=n_{i} / n$ is the relative proportion of the content in plant tissues of the $i$-th element of the set. Informational function (1) is used for a quantitative determination of the measure of organization or diversity of the multi-component subsystems. Under such an approach, we can obtain quantitative information on the dynamics of the entire multi-component system. For example, the values of $p_{i}$ are calculated from the data on the content (percentage) of organic matter components in mineral substrate and biotic community (percentage) for each growth period (vegetation). The qualitative dynamics of the information functions bear resemblance for the organic matter and microbial communities (Fig.2). It was shown earlier [3] that the information exchange between multi-component systems of the organic matter and biotic community significantly affects the vital activity of the plant. This is reflected in variations of the plants productivity dynamics [3]. 


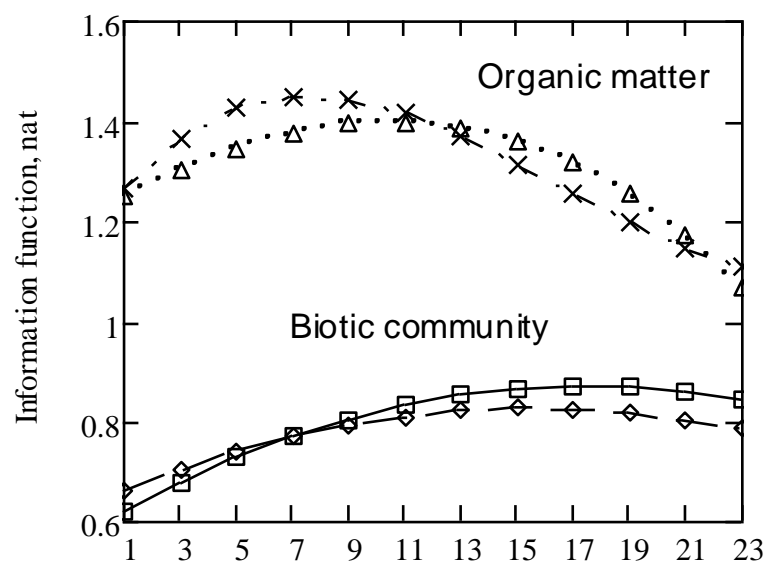

Vegetation

Fig. 2: The dynamics of the information function (the trend) for organic matter and biotic community. Crushed granite. Organic substance: $\cdot \Delta \cdot \cdot$. Tomato plants. $-\odot-$ Spring wheat variant. Biotic community: $\neg \square$ Tomato plants. $-\diamond-$ Spring wheat.

Populations of fungi give off significant amounts of organic acids, thereby accelerating the weathering of minerals and the soil formation processes [13]. For example, fungi actively produce fulvic acids. The number of fungi in the crushed granite has the same procedure of magnitude both the cultivation tomato as well as spring wheat. Up to eleventh vegetation cycle the number of fungi in the zeolite is higher than in the crushed granite. Then, the number of fungi is reduced to a level consistent with the crushed granite. The number of fungi has increased from 15.6 to 56.4 thousand per gram of dry substrate, and the number of actinomycetes increased from zero to 63.8 thousand per gram of dry substrate during that time. The seaweed of four divisions are developing into substrates regardless of mineral substrate and varieties of plants: Cyanophyta, Chlorophyta, Chrysophyta, Bacillariophyta. We found diatoms (Bacillariophyta) on the surface of granules of the mineral substrates and plant roots. As it is well known [10], diatoms are actively involved in the cycle of silicon in the system of plants - mineral substrate.

We already found changes in the mineral substrate after the twelfth vegetation. It will be note the greatest changes have taken place in the mineralogical composition of three factions the following size: 0.01-0.25, $0.005-0.01$ and $<0.005 \mathrm{~mm}$. The bulk of the fine earth of the starting rubble consists of quartz and feldspar.

Our researches have shown that the impact of living matter leads to the splitting-off of mica from the rubble. These processes result enrich of fine earth. The trioctahedral mica more actively passes into the fine earth than the dioctahedral mica. The action of living matter changes the ratio between fractions of the mineral substrate. So, for example, after twelve vegetation cycles (variant with tomato) the largest quantity of fractions of size $5-9 \mathrm{~mm}$ of crushed granite is reduced from $95.5 \%$ (initial granite) to $89.6 \%$. In case we cultivated the spring wheat the quantity of these fractions is reduced to $88.2 \%$. The content of crushed stone fines $(<$ $0.25 \mathrm{~mm}$ ) is increased from $0.09 \%$ (initial granite) to $0.73 \%$ (variant with tomato) while at growing of the spring wheat the quantity of crushed stone fines is increased to $2.41 \%$. \%. For the initial crushed granite total percentage of fractions of size $<0.01 \mathrm{~mm}$ is equal to $15 \%$. After the twelve vegetations the content of these fractions is increased to $48 \%$. That is, we have observed grinding of the mineral substrate under the influence of living substance. Our investigations have shown that changes in the mineralogical composition of particles in the size $0.005-0.01 \mathrm{~mm}$ are associated with increasing of contents kaolinite, chlorite and mica. The mineralogical composition of this fraction is significantly different from the starting granite (Table 1).

The experiment showed that by the end of the twenty-third of vegetation the cultivation of tomato and wheat using the granite rubble leads to the enrichment of large granule (granules of size $0.01-0.25 \mathrm{~mm}$ ) by quartz, trioctahedral mica and chlorite. At the same time, these fractions are impoverished by the feldspar. Herewith there was a noticeable dilution of the mineral substrate by the amorphous fraction. A comparison of the experimental results showed that spring wheat is more aggressive agent of weathering than the tomato. After the twenty-three vegetations the number of corroded and fractured granules is increased. 
Journal of Advances in Natural Sciences

Comparative data of mineralogical composition of crushed granite by X-ray method is provided in the Table 1 .

Table 1. The mineralogical composition of the initial crushed granite and after cultivation of tomato plants during the twenty-third of vegetation cycles. Fractions of size $0.50-0.25 \mathrm{~mm}$.

\begin{tabular}{|c|c|c|c|c|c|c|c|c|}
\hline \multirow{3}{*}{ Mineral substrate } & \multicolumn{6}{|c|}{ Minerals, \% } & \multicolumn{2}{|c|}{$\begin{array}{c}\text { New formations, } \\
\%\end{array}$} \\
\hline & \multirow[b]{2}{*}{ 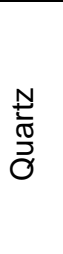 } & \multirow[b]{2}{*}{$\begin{array}{l}\overline{\bar{\sigma}} \\
\frac{0}{0} \\
\frac{0}{0} \\
\\
L\end{array}$} & \multirow[b]{2}{*}{ 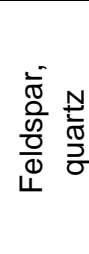 } & \multicolumn{2}{|c|}{ Micas } & \multirow[b]{2}{*}{$\begin{array}{l}\frac{\infty}{\Phi} \\
\frac{0}{ \pm}\end{array}$} & \multirow{2}{*}{ 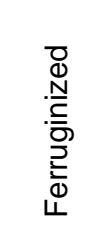 } & \multirow{2}{*}{ 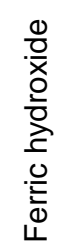 } \\
\hline & & & & 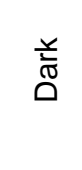 & $\begin{array}{l}\overline{0} \\
\frac{\Phi}{0} \\
\frac{0}{0} \\
\frac{.0}{0} \\
\end{array}$ & & & \\
\hline Initial crushed granite & 53.3 & 36.0 & 0.7 & 6.0 & - & 4.0 & - & - \\
\hline $\begin{array}{l}\text { Crushed granite } \\
\text { after of } 23 \text { th vegetations }\end{array}$ & 47.5 & 22.0 & 0.5 & 12.0 & 2.0 & 2.0 & 10.0 & 5.0 \\
\hline
\end{tabular}

New formations are presented by ferriferous films and formation of iron hydroxide. As is well known, the formation of secondary minerals is a sign of soil-forming processes. In addition, on the surface of the mineral granules is formed the organic film and film of organo-mineral compounds. These adsorbed organic films include simple phenols, phenolcarbonic acids, amino acids and humic substances. The organic films have a strong effect on the mineral surface as well as microbial cells, algae, and fungi. Such changes are a convincing proof of the transformation inert mineral substrates into soil-like bodies. Additionally, the organomineral agregates rounded shape began to appear. These agregates are characteristic for humic soil horizons of humid zone. Enrichment thinly disperse fractions by kaolinite around the roots indicates the aggressiveness of root exudates. As a result of higher plants cultivation granite rubble loses the sharp splits, the shape of granules becomes rounded on the surface of minerals, the roots leave channels and deep hollows.

In Tables 2 and 3 are listed the data obtained. Using these data we can quantitatively determine the dynamics of the chemical elements migration and bioavailability for plants [2] from the mineral substrate. This is especially important for the starting vegetations when the process formation of biotic community and organic matter has only just begun into the mineral substrate. The substantial variations of relative content of the chemical elements in the different plant tissues of spring wheat and tomato plants do not affect on the mutual relations between the chemical element contents. It is significant to note that a change in the relative content of the chemical elements $(P, S, C l, C a, M g, N a, K, F e, S i, A l, M n$, $\mathrm{Zn}$ ) does not alter the sequence of information functions (2) for plant tissues. Information approach meets with success for study of the dynamics of multi-component systems [14,15].

Table 2. The dynamics of the relative content of chemical elements in mineral substrates when their prolonged operation.

\begin{tabular}{|c|c|c|c|c|c|c|c|c|c|c|c|c|}
\hline \multirow[b]{2}{*}{$j$} & \multicolumn{12}{|c|}{$\begin{array}{l}\text { The weight fraction of the chemical elements in mineral substrates } \\
\text { (composition of the roasted sample in \%) }\end{array}$} \\
\hline & $\mathrm{SiO}_{2}$ & $\mathrm{Al}_{2} \mathrm{O}_{3}$ & $\mathrm{Fe}_{2} \mathrm{O}_{3}$ & $\mathrm{TiO}_{2}$ & $P_{2} \mathrm{O}_{5}$ & $\mathrm{MnO}$ & $\mathrm{CaO}$ & $\mathrm{MgO}$ & $K_{2} \mathrm{O}$ & $\mathrm{Na}_{2} \mathrm{O}$ & $\mathrm{SO}_{3}$ & $\begin{array}{l}H, \\
D\end{array}$ \\
\hline \multicolumn{13}{|c|}{ Initial crushed granite } \\
\hline \multirow[t]{3}{*}{1} & 74.14 & 12.77 & 2.98 & 0.40 & 0.19 & 0.06 & 1.46 & 1.17 & 5.93 & 0.50 & 0.49 & $\begin{array}{c}0.9617 \\
0.599\end{array}$ \\
\hline & & & & & & & & & & & & \\
\hline & 0.741 & 0.128 & 0.030 & 0.004 & 0.002 & $6 \cdot 10^{-4}$ & 0.015 & 0.012 & 0.059 & 0.005 & 0.005 & $\begin{array}{c}0.9617 \\
0.599\end{array}$ \\
\hline \multicolumn{13}{|c|}{ Crushed granite. Tomato plants. After of the fifteenth vegetation cycle } \\
\hline 2 & 68.80 & 11.20 & 7.10 & 0.75 & 1.23 & 0.06 & 3.78 & 1.71 & 2.94 & 1.80 & 0.38 & $\begin{array}{c}1,1765 \\
0.509\end{array}$ \\
\hline \multirow{2}{*}{\multicolumn{13}{|c|}{ Crushed granite. Tomato plants. After of the twenty-third vegetation }} \\
\hline 3 & & & & & & & & & & 0.49 & 0.30 & 1,1500 \\
\hline
\end{tabular}

$269 \mid$ P a g e 
ISSN $2393-9257$

Volume 3 Number 2

Journal of Advances in Natural Sciences

\begin{tabular}{|c|c|c|c|c|c|c|c|c|c|c|c|c|}
\hline & & & & & & & & & & & & \\
\hline & & & & \\
\hline
\end{tabular}

$\left.{ }^{*}\right) p_{i}$ is the sampling fraction of the chemical elements content. We did not make measurements of zinc content in mineral substrates.

Table 3. The dynamics of chemical elements in the roots (plant tissues) plants under long-term culturing on mineral substrates

\begin{tabular}{|c|c|c|c|c|c|c|c|c|c|c|c|c|c|}
\hline \multirow{2}{*}{ № } & \multicolumn{13}{|c|}{ Relative content (ash composition, \%) of the chemical elements in plant tissues } \\
\hline & $\mathrm{SiO} 2$ & A/2O3 & $\mathrm{Fe} 2 \mathrm{O3}$ & $\mathrm{ZnO}$ & $P 205$ & $\mathrm{MnO}$ & $\mathrm{CaO}$ & $\mathrm{MgO}$ & $\mathrm{K} 2 \mathrm{O}$ & $\mathrm{Na2O}$ & SO3 & $\mathrm{Cl}$ & $\begin{array}{l}H, \\
D\end{array}$ \\
\hline \multirow{2}{*}{\multicolumn{14}{|c|}{ Crushed granite. Tomato plants. After of the first vegetation cycle }} \\
\hline \multicolumn{12}{|c|}{ Roots } & & \\
\hline \multirow{3}{*}{16} & 10.39 & 1.03 & 1.47 & 0.332 & 16.28 & 0.11 & 36.39 & 6.20 & 15.82 & 6.01 & 5.52 & 1.16 & $\begin{array}{c}1.8727 \\
0.246\end{array}$ \\
\hline & \multicolumn{13}{|c|}{ pi } \\
\hline & 0.103 & 0.010 & 0.015 & 0.003 & 0.162 & 0.001 & 0.361 & 0.062 & 0.157 & 0.060 & 0.055 & 0.012 & $\begin{array}{c}1.8727 \\
0.246\end{array}$ \\
\hline \multicolumn{14}{|c|}{ Leafs } \\
\hline 17 & 1.90 & 0.066 & 0.17 & 0.053 & 13.45 & 0.11 & 32.57 & 8.98 & 26.82 & 0.47 & 14.00 & 1.32 & $\begin{array}{c}1.6711 \\
0.327\end{array}$ \\
\hline \multicolumn{14}{|c|}{ Stems } \\
\hline 18 & 0.20 & 0.015 & 0.037 & 0.187 & 10.07 & 0.059 & 26.62 & 12.88 & 32.89 & 0.73 & 13.98 & 2.37 & $\begin{array}{c}1.6454 \\
0.515 \\
\end{array}$ \\
\hline
\end{tabular}

270 | P a g e 
ISSN $2393-9257$

Volume 3 Number 2

Journal of Advances in Natural Sciences

\begin{tabular}{|c|c|c|c|c|c|c|c|c|c|c|c|c|c|}
\hline 19 & 0.16 & 0.018 & 0.06 & \begin{tabular}{l|}
0.049 \\
\end{tabular} & 27.84 & 0.059 & 3.36 & 7.08 & 44.43 & 0.96 & 10.96 & 4.20 & $\begin{array}{l}1.4663 \\
0.410\end{array}$ \\
\hline \multicolumn{14}{|c|}{ Crushed granite. Tomato plants. After of the fifteenth vegetation cycle. } \\
\hline \multicolumn{14}{|c|}{ Roots } \\
\hline 20 & 11.2 & 0.28 & 0.51 & 0.59 & 16.6 & 0.17 & 35.0 & 3.21 & 18.8 & 0.58 & 13.0 & 0.34 & $\begin{array}{l}1.7323 \\
0.303\end{array}$ \\
\hline \multicolumn{14}{|c|}{ Leafs } \\
\hline 21 & 0.77 & 0.077 & 0.08 & \begin{tabular}{l|l}
0.026 \\
\end{tabular} & 9.57 & 0.115 & 34.41 & 8.70 & 20.42 & 0.92 & 23.77 & 0.86 & $\begin{array}{c}1.6149 \\
0.350\end{array}$ \\
\hline \multicolumn{14}{|c|}{ Stems } \\
\hline 22 & 0.21 & 0.007 & 0.024 & 0.042 & 8.97 & 0.044 & 31.68 & 3.34 & 44.04 & 0.98 & 7.77 & 2.89 & $\begin{array}{l}1.4237 \\
0.427\end{array}$ \\
\hline \multicolumn{14}{|c|}{ Fruits } \\
\hline 23 & 1.21 & 0.054 & 0.078 & 0.019 & 16.08 & 0.149 & 1.12 & 1.44 & 66.2 & 2.62 & 9.89 & 1.05 & $\begin{array}{l}1.1249 \\
0.547\end{array}$ \\
\hline \multirow{2}{*}{\multicolumn{14}{|c|}{$\begin{array}{l}\text { Crushed granite. Tomato plants. After of the twenty-third vegetation cycle. } \\
\text { Roots }\end{array}$}} \\
\hline & & & & & & & & & & & & & \\
\hline 24 & 3.30 & 0.21 & 0.50 & 0.10 & 27.19 & 0.04 & 28.90 & 4.83 & 22.8 & 0.42 & 11.90 & 0.44 & $\begin{array}{c}1.6544 \\
0.334\end{array}$ \\
\hline \multicolumn{14}{|c|}{ Leafs } \\
\hline 25 & 1.06 & 0.01 & 0.132 & \begin{tabular}{|l|}
0.019 \\
\end{tabular} & 9.49 & 0.032 & 28.98 & 5.98 & 26.24 & 0.55 & 25.92 & 0.72 & $\begin{array}{c}1.5832 \\
0.363\end{array}$ \\
\hline \multicolumn{14}{|c|}{ Stems } \\
\hline 26 & 0.49 & 0.03 & 0.102 & \begin{tabular}{|c|}
0.049 \\
\end{tabular} & 12.61 & 0.007 & 22.47 & 6.39 & 45.07 & 1.52 & 10.28 & 1.09 & $\begin{array}{c}1.5184 \\
0.389\end{array}$ \\
\hline \multicolumn{14}{|c|}{$\frac{1}{\text { Fruits }}$} \\
\hline 27 & 1.42 & 0.15 & 0.113 & 0.041 & 15.17 & 0.026 & 2.25 & 6.10 & 54.92 & 2.77 & 14.84 & 2.35 & $\begin{array}{c}1.4238 \\
0.427\end{array}$ \\
\hline \multirow{2}{*}{\multicolumn{14}{|c|}{$\begin{array}{l}\text { Crushed granite. Spring wheat. After of the first vegetation cycle. } \\
\text { Roots }\end{array}$}} \\
\hline & & & & & & & & & & & & & \\
\hline 28 & 11.86 & 1.25 & 1.10 & 0.184 & 22.56 & 0.089 & 34.18 & 0.81 & 23.10 & 1.44 & 3.44 & 0.50 & $\begin{array}{c}1.6556 \\
0.334\end{array}$ \\
\hline \multicolumn{14}{|c|}{ Culms } \\
\hline 29 & 2.27 & 0.026 & 0.046 & \begin{tabular}{|c|}
0.099 \\
\end{tabular} & 5.94 & \begin{tabular}{|l|}
0.048 \\
\end{tabular} & 29.78 & 6.93 & 41.49 & 1.90 & 9.81 & 2.23 & $\begin{array}{l}1.5652 \\
0.370\end{array}$ \\
\hline \multicolumn{14}{|c|}{ Grains } \\
\hline 30 & 0.11 & 0.02 & 0.10 & 0.209 & 37.49 & 0.104 & 2.95 & 9.08 & 28.27 & 1.209 & 20.17 & 1.02 & $\begin{array}{l}1.5023 \\
0.395\end{array}$ \\
\hline \multirow{2}{*}{\multicolumn{14}{|c|}{$\begin{aligned} \text { Crushed granite. Spring wheat. After of the fifteenth vegetation cycle } \\
\text { Roots }\end{aligned}$}} \\
\hline & & & & & & & & & & & & & \\
\hline 31 & 7.37 & 0.70 & 0.84 & 0.10 & $\begin{array}{l}16.2 \\
\end{array}$ & 0.049 & 30.5 & 3.44 & 25.8 & 2.98 & 10.1 & 1.37 & $\begin{array}{l}1.8000 \\
0.276\end{array}$ \\
\hline \multicolumn{14}{|c|}{ Culms } \\
\hline 32 & 1.64 & 0.078 & 0.041 & 0.017 & 7.67 & 0.172 & 21.76 & 7.72 & 39.97 & 1.54 & 9.71 & 7.22 & $\begin{array}{c}1.6792 \\
0.324\end{array}$ \\
\hline \multicolumn{14}{|c|}{ Grains } \\
\hline 33 & 2.66 & 0.012 & 0.086 & 0.269 & 42.49 & 0.116 & 3.40 & 7.93 & 31.32 & 1.43 & 7.36 & 2.75 & $\begin{array}{l}1.5231 \\
0.387\end{array}$ \\
\hline \multirow{2}{*}{\multicolumn{14}{|c|}{$\begin{array}{c}\text { Crushed granite. Spring wheat. After of the twenty-third vegetation cycle } \\
\text { Roots }\end{array}$}} \\
\hline & & & & & & & & & & & & & \\
\hline 34 & 5.71 & 0.34 & 0.53 & 0.096 & 24.85 & 0.06 & 24.29 & 6.34 & 22.20 & 2.44 & 10.95 & 2.84 & $\begin{array}{l}1.8508 \\
0.255\end{array}$ \\
\hline \multicolumn{14}{|c|}{ Culms } \\
\hline 35 & 2.25 & 0.19 & 0.37 & \begin{tabular}{|c|}
0.085 \\
\end{tabular} & 6.55 & 0.196 & 15.68 & 6.82 & 45.08 & 1.49 & 17.27 & 3.84 & $\begin{array}{l}1.6399 \\
0.340\end{array}$ \\
\hline \multicolumn{14}{|c|}{ Grains } \\
\hline 36 & 2.26 & 0.23 & 0.17 & 0.111 & 32.82 & 0.03 & 4.55 & 9.84 & 36.20 & 1.11 & 12.58 & 0.38 & $\begin{array}{l}1.5531 \\
0.375\end{array}$ \\
\hline \multirow{2}{*}{\multicolumn{14}{|c|}{$\begin{array}{l}\text { Zeolite. Tomato plants. After of the first vegetation cycle } \\
\text { Roots }\end{array}$}} \\
\hline & & & & & & & & & & & & & \\
\hline 37 & 23.2 & 1.95 & 4.19 & 0.07 & 6.81 & 0.22 & 29.6 & 7.20 & 15.7 & 5.12 & 3.89 & 2.05 & 1.9487 \\
\hline
\end{tabular}

271 | P a g e 
ISSN $2393-9257$

Volume 3 Number 2

Journal of Advances in Natural Sciences

\begin{tabular}{|c|c|c|c|c|c|c|c|c|c|c|c|c|c|}
\hline & & & & & & & & & & & & & 0.216 \\
\hline \multicolumn{14}{|c|}{ Leafs } \\
\hline 38 & 2.08 & 0.053 & 0.10 & 0.019 & 6.42 & 0.13 & 36.86 & 12.87 & 23.35 & 0.78 & 16.16 & 1.04 & $\begin{array}{c}1.6301 \\
0.344\end{array}$ \\
\hline \multicolumn{14}{|c|}{ Stems } \\
\hline 39 & 0.22 & 0.011 & 0.03 & 0.122 & 6.25 & 0.081 & 35.58 & 13.59 & 32.58 & 2.41 & 9.11 & 1.41 & $\begin{array}{c}1.5691 \\
0.369\end{array}$ \\
\hline \multicolumn{14}{|c|}{ Fruits } \\
\hline 40 & 0.204 & 0.008 & 0.082 & 0.028 & 21.96 & 0.072 & 3.00 & 7.86 & 46.25 & 1.20 & 14.66 & 3.81 & $\begin{array}{c}1.4825 \\
0.403\end{array}$ \\
\hline \multicolumn{14}{|c|}{ Zeolite. Tomato plants. After of the twelve vegetation cycle } \\
\hline \multicolumn{14}{|c|}{ Roots } \\
\hline 41 & 16.6 & 1.67 & 1.06 & 0.04 & 3.72 & 0.08 & 42.0 & 9.55 & 11.2 & 1.08 & 11.7 & 1.27 & $\begin{array}{c}1.7349 \\
0.301\end{array}$ \\
\hline \multicolumn{14}{|c|}{ Leafs } \\
\hline 42 & 0.56 & 0.057 & 0.121 & 0.025 & 9.86 & 0.063 & 36.33 & 7.53 & 18.81 & 1.03 & 24.87 & 0.77 & $\begin{array}{c}1.5840 \\
0.363\end{array}$ \\
\hline \multicolumn{14}{|c|}{ Stems } \\
\hline 43 & 0.083 & 0.013 & 0.023 & 0.035 & 12.39 & 0.04 & 32.96 & 4.98 & 36.83 & 1.24 & 9.09 & 2.37 & $\begin{array}{c}1.5175 \\
0.389\end{array}$ \\
\hline \multicolumn{14}{|c|}{ Fruits } \\
\hline 44 & 0.85 & 0.031 & 0.13 & 0.008 & 21.90 & 0.157 & 1.25 & 0.83 & 63.05 & 1.36 & 7.92 & 2.62 & $\begin{array}{c}1.1343 \\
0.544\end{array}$ \\
\hline
\end{tabular}

Using the definition of information function we have obtained the following sequence of inequalities:

$H($ roots $)>H($ leafs $) \geq H($ stems $)>H($ reproductive organs $)$.

This sequence of the inequalities does not depend of number of vegetation cycles. A similar sequence of inequalities (2) was initiated when we cultivated the spring wheat. According to our studies [4,5] the sequence of inequalities is also satisfied at growing plants on the zeolite. However, the dynamics of the information function for roots is not simultaneous [13] in respect to the dynamics of the information functions for the leaves, stems, and reproductive organs. At the same time, the ash content of the plant roots is reduced [16] as exploiting of mineral substrates is increased.

Under the bioavailability we mean the ratio of elements quantity absorbed by plant roots to the quantity of the chemical element in the rock (Table 4). Chemical elements $\mathrm{Si}, \mathrm{Al}, \mathrm{Fe}, \mathrm{Mn}, \mathrm{Na}$, can be absorbed only from mineral substrates. The absorption of these elements by plants may be due to only destruction of mineral substrate. It should be borne in mind that for the rest chemical elements, this ratio can be regarded as the relative "pseudomigration".

Tabulated data demonstrates (Table 4) that the absorption of chemical elements by the plant roots is realized in other proportions than their content in the mineral substrate. The chemical composition of plant tissues is significantly different from the granite chemical composition (see Tables 2 and 3). There has been a significant absorption of chemical elements $\mathrm{Si}, \mathrm{Al}, \mathrm{Fe}, \mathrm{Mn}, \mathrm{Na}$ by plants root. Pseudomigration of chemical elements also varies considerably. For example, using the data in Tables 2 and 3, we have (granite substrate) the following sequence of inequalities (tomato plants) for phosphorus $\mathrm{P}_{2} \mathrm{O}_{5}$ (roots) $/ \mathrm{P}_{2} \mathrm{O}_{5}$ (granite): 85.7 (after of the first growing season) $>16.4(13.5)$ (after of the fifteenth growing season) $<$ 35.8(143.1)(after twenty-third growing season). The similar sequence was found for wheat: 195.5(after of the first growing season) < 28.6(130.8)(after of the twenty-third growing season). The substantial variation in the bioavailability of phosphorus may be due to changes in the availability of phosphorus for plants from the mineral substrate.

We have found that the ash content of the plant tissue is changed with increasing duration of mineral substrates use. For example, the ash content of the tomato roots relative to the dry mass of roots is equal to 33.8 and $19.5 \%$ after of the first vegetation and after the twenty-third vegetation, respectively.

As part of study the maximum of ash content of root plants is observed for the first vegetations. For the roots of spring wheat the ash content are equal 42.4 and $21.4 \%$ over the same period of time, respectively. The ash content of tomato leaves is reduced by $5 \%$ within that period of observation. At the same time for the stems and reproductive organs the ash content are increased to $15-20 \%$ [16].

For the zeolite the processes of accumulation of the organic matter are analogous to the processes in the granite rubble. However, in the zeolite accumulation of the organic matter occurs markedly more actively. The zeolite has got initially more favorable agrobiological properties than the granite rubble. This is due to the fact that the zeolite granules with more developed a specific surface. Figure 3 shows the dynamics of the ratio of the total carbon content $\left(C_{\text {zolite }}\right)$ for the zeolite to the total carbon content $\left(C_{\text {granite }}\right)$ for the crushed granite (ratio $C_{z e o l i t e} / C_{\text {granite }}>1$ ). This inequality is persisted greater than unity during the entire experiment. 
Journal of Advances in Natural Sciences Number of fungi in the zeolite is considerably greater than their number in crushed granite especially for first vegetations. This is apparently due to the presence into zeolite of large number of micro-pores and micro-capillaries in which already a micro-colonies of microorganisms were before the exploitation of the mineral substrate.

The multifarious community of fungi is formed in the mineral substrate after the first growing season. After the twelfth vegetation the number of different species of fungi in the zeolite increases by one and a half times and the number of fungi increases by an order of magnitude compared to granite rubble. For zeolite the number of the spore-forming bacteria increased almost 40 times after crop rotation.

X-ray analysis demonstrated that the intensive operation of the zeolite leads to an increase in the portion of clinoptilolite in the fine fraction. The same time the portion of the quartz is decreased. Intensive use of the zeolite has resulted in a noticeable change in its fractional composition.

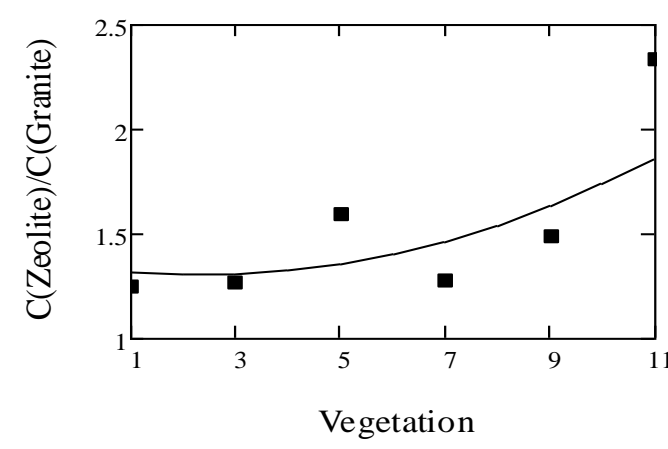

A

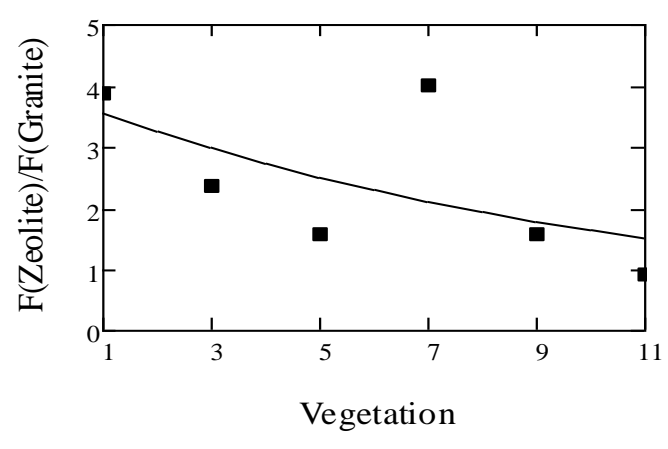

B

Fig. 3: (A). The dynamics of the ratio of total carbon $(C)$ for crushed granite and zeolite. (B). The dynamics of the ratio of quantity fungi $(F)$ for crushed granite and zeolite. Tomato plants. I the experiment, — the trend.

Table 4. The dynamics of bioavailability of chemical elements ${ }^{*}$

\begin{tabular}{|c|c|c|c|c|c|}
\hline Vegetation & $\frac{\mathrm{Na}_{2} \mathrm{O} \text { (roots) }}{\left.\mathrm{Na}_{2} \mathrm{O} \text { (substrate }\right)}$ & $\frac{M n O(\text { roots })}{M n O(\text { substrate })}$ & $\begin{array}{c}\mathrm{Fe}_{2} \mathrm{O}_{\mathrm{e}_{2}} \mathrm{O}_{3} \text { (soots) } \\
\text { (substrate) }\end{array}$ & $\frac{\mathrm{SiO}_{2}}{\mathrm{SiO}_{2}}=\frac{\text { (roots) }}{\text { substrate })}$ & $\begin{array}{c}\mathrm{Al}_{2} \underline{\mathrm{O}}_{2} \\
\mathrm{O}_{2} \text { (roots) } \\
\text { (substrate) }\end{array}$ \\
\hline \multicolumn{6}{|c|}{ Crushed granite. Tomato plants } \\
\hline 1 & 12.0 & 1.83 & 0.49 & 0.14 & 0.08 \\
\hline 15 & $0.21(0.32)$ & $1.70(2.87)$ & $0.07(0.07)$ & $0.15(0.16)$ & $0.03(0.025)$ \\
\hline 23 & $0.86(0.86)$ & $0.29(0.67)$ & $0.05(0.17)$ & $0.05(0.045)$ & $0.02(0.016)$ \\
\hline \multicolumn{6}{|c|}{ Crushed granite. Spring wheat } \\
\hline 1 & 0.16 & 2.4 & 0.27 & 0.24 & 0.09 \\
\hline 23 & $4.69(4.88)$ & $1.2(1.00)$ & $0.05(0.18)$ & $0.08(0.077)$ & $0.04(0.027)$ \\
\hline \multicolumn{6}{|c|}{ Zeolite. Tomato plants } \\
\hline 1 & 4.07 & 2.22 & 0.93 & 0.36 & 0.13 \\
\hline 11 & $1.57(0.84)$ & $1.29(0.78)$ & $0.25(0.23)$ & $0.36(0.26)$ & $0.09(0.11)$ \\
\hline
\end{tabular}

In brackets the bioavailability is indicated with respect to the starting material substrate.

By analogy to the granite the solid particles of the zeolite are milled to fine particles. So, for example, quantity granules of the zeolite of size $5-9 \mathrm{~mm}$ is reduced from $75.4 \%$ (initial zeolite) to $62.2 \%$ (after the twelfth vegetation; tomato plants). The number of granules of size $<0.25 \mathrm{~mm}$ is increased from $2.4 \%$ (initial zeolite) to $11.8 \%$ (after of the twelfth vegetation; tomato plants). After of the twelve vegetation cycles the total percentage of fractions $<0.01 \mathrm{~mm}$ increases from $56 \%$ to $63 \%$. The quantity of the fractions (size of 0.001 $0.005 \mathrm{~mm}$ ) is increased more than twice. The fine fractions (size of $<0.001 \mathrm{~mm}$ ) are turned into the ooze status. The zeolite (after of the exploitation) is a relatively pure clinoptilolite with small amounts of quartz and feldspar.

Our studies have shown that in close proximity to the roots the mineral substrate is subjected to intensive influence of metabolites of vital activity of the plant root system. We can expect that in area of roots the 
Journal of Advances in $\mathrm{Natural} \mathrm{Sciences}$ chemical composition of the mineral substrate will be substantially different from that of the initial substrate. Micas, chlorites, and amphiboles have easily accessible nutrients for plant. They accumulate around the roots in a greater concentration than the more stable feldspar. Wash-off from surface of roots contains less of quartz than in the initial granules of the crushed granite. We found that the surface layers of the crushed granite particles (size of $\sim 0.1 \mathrm{~mm}$ ) are depleted by oxide $\mathrm{Al}_{2} \mathrm{O}_{3}, \mathrm{MgO}, \mathrm{K}_{2} \mathrm{O}$. At the same time these layers are enriched with amorphous silicic acid.

Experimental data (Table 2 and 3) show that the fine earth is enriched by kaolinite around plant roots. This points the aggressiveness of root exudates, at that the aggressiveness of the wheat roots was higher than activity tomato roots. Experimental data in Tables 2 and 3 allow us to obtain the dynamics of evolutionary transformation of the content of chemical elements in the mineral substrate and evolution of the content of chemical elements in the roots of tomato plants. Using the dimensionless information redundancy function $D_{j}$ we have obtained the following sequence of inequalities: (crushed granite; tomato plants):

$$
\begin{aligned}
& D_{1}=0.599>D_{4}=0.585>D_{7}=0.510>D_{2}=0.509>D_{8}=0.409>D_{9}=0.384> \\
& D_{6}=0.382>D_{11}=0.346>D_{24}=0.334 \geq D_{5}=0.330>D_{10}=0.223,
\end{aligned}
$$

here $j$ is number in Tables 2 and 3 . The sequence of inequalities is arranged in the order of increasing exploitation duration of the mineral substrate. We obtained the following sequence of inequalities when we cultivated of spring wheat (crushed granite):

$$
D_{1}=0.599>D_{13}=0.514>D_{12}=0.355>D_{11}=0.347>D_{28}=0.334>D_{31}=0.276>D_{34}=0.255 \text {. }
$$

The redundancy function $D$ is as follows: $D=1-H / H_{\max }$, here $H_{\max }=\ln (\mathrm{n})$ is the maximum values possible of the information function for the set of $n$ elements (set of $n$ elements). Redundancy function allows us to compare the information content of the set with a various number of elements $n$. From these inequalities (3) and (4) it follows that with increasing of the vegetations number the information content of crushed granite in close proximity to plant roots (characterized by the redundancy function $D_{j}$ ) is approximated to the information content of root plants. Not only the initial granite rubble granules are modified, but fine earth is also transformed: $H_{4}=0.996<H_{6}=1.481$ nat $\left(D_{4}=0.585>D_{6}=0.382\right)$. The more mineral substrate is transformed, the information function of the minerals closer to the information function of the roots. The evolutionary development of the mineral substrates in the root zone of plants is determined, above all, by the information aspect, without regard on the energy process.

As shown in the paper [2], the ratio $\mathrm{CaO} / \mathrm{Al}_{2} \mathrm{O}_{3}$ characterizes the modification of the mineral substrate. The dynamics of change in calcium-to-aluminum ratio $\left(\mathrm{CaO} / \mathrm{Al}_{2} \mathrm{O}_{3}\right)$ in transformed granite may be written as follows:

$\mathrm{CaO}(1) / \mathrm{Al}_{2} \mathrm{O}_{3}(1)=0.114<\mathrm{CaO}(4) / \mathrm{Al}_{2} \mathrm{O}_{3}(4)=0.292<<\mathrm{CaO}(5) / \mathrm{Al}_{2} \mathrm{O}_{3}(5)=2.745<\mathrm{CaO}(10) / \mathrm{Al}_{2} \mathrm{O}_{3}(10)=3.713$.

Numbers $1,4,5$, and 10 correspond to the positions in Table 1 . The higher the molecular ratio $\left(\mathrm{CaO} / \mathrm{Al}_{2} \mathrm{O}_{3}\right)$ the mineral substrate more modified.

X-ray analysis demonstrated that in the initial zeolite and zeolite after exploiting there are changes in the chemical composition as well as in the crushed granite. X-ray data was obtained for the fractions of the material which were washed away from the roots and also for the melkozem of zeolite. These data indicate that the composition of mineral substrate which is accumulated in the activity area of the roots and in the fine earth close to composition of plant roots. The most modified zeolite also accumulates in the oozy fraction.

\section{CONCLUSION}

Round-the-year, uninterrupted, and long-term growing of spring wheat and tomato plants on mineral substrates (crushed granite, zeolite) has demonstrated that under controlled conditions is happening a biogenic and physicochemical weathering of minerals. Cultivation of higher plants on mineral substrates is accompanied by intensive the colonization of substrates by the protozoa (nematodes, algae, etc.) and 
Journal of Advances in $\mathrm{Natural} \mathrm{Sciences}$ numerous micro-organisms (fungi, bacteria, actinomycetes). Herewith, in the course of exploitation the minerals are subjected to intense weathering. The result of a biogenic weathering of minerals is crushing of rock, washing-out of ash constituent, the transformation of fine earth, formation of secondary minerals. An important component of these processes is the formation of humus, which is a complex organic compounds different nature. These chemical compounds define the key property of soil (chemical, physical, physicochemical and biological). Intense accumulation of the organic matter is carried out for a very short period of time. Microbiological studies of mineral substrates showed that the emerging community of microorganisms is comparable with natural soils by qualitative and quantitative composition. As a result of microbial activity are formed acids and bases, which is favorable for the transformation of minerals. That is this situation is similar to natural settings. There is a relationship between the dynamics of quantitative and qualitative composition of the multi-component organic matter and the development of multi-component biotic communities. The collective action of the living matter on mineral substrates leads to changes in the properties of the bioavailability of chemical elements for plants. These biochemical and physicochemical processes of primary soil formation are synchronously realized in close interaction under active participation of higher plants. Primary soil formation processes contribute to the flow of mineral elements in plants directly from the minerals. The consequence of the interaction of living matter with the substrate material is a transformation of the constituent minerals. These processes along with the processes of humus formation are an important feature of the primary soil. That is, the soil-forming process involves an exchange between the living matter and mineral substrate by mineral elements. According to our study, the living matter is actively involved in soil formation processes already during the first growing season.

\section{REFERENCES}

I. Vernadskiy, V., 1978, Zhivoye veshchestvo (Vernadsky,V. 1978, Living substance). M.: Nauka, 358 p. (in Russian)

II. Polynov, B., 1956, Pervyye stadii pochvoobrazovaniya na massivno-kristallicheskikh porodakh. Izbrannyye trudy (Polynov, B., The first stages of soil formation on massive crystalline rocks. Selected works. M.: USSR Academy of Sciences,). M.: Izd. AN SSSR M.: USSR Academy of Sciences. (in Russian).

III. Mukhomorov, V., 2014, The Dynamics of Plant Productivity Under Controlled Conditions. Diversity or Information Exchange?, Trends J. of Sci. Res. 1(Jan. 2014), 17-25.

IV. Mukhomorov,V. and Anikina, L., 2012, Dynamics of Mineral Elements in Plants. Primary Soil Formation. LAMBERT Academic Publishing. Saarbrücken. (in Russian).

V. Mukhomorov, V., and Anikina, L., 2014, Evolutionary Dynamics of Intercoupling of the Chemical Elements in Plants and Primary Soil-Forming Processes, Trends J. of Sci. Res, 1(Jan. 2014), 1-11.

VI. Komissarov, I.D., Strel'tsova, I.N., Kuznetsova, T.P., 1979, Pochvoobrazovaniye v tekhnogennykh landshaftakh. Novosibirsk. (Soil formation in technogenic landscapes, 1979), Nauka. (in Russian).

VII. Orlov, D.S.,1992, Khimiya pochv. M.: Izd. MGU (Soil Chemistry, 1992, M.: Moscow State University), 400 p. (in Russian).

VIII. Guminovyye veshchestva v biosfere. Red. Orlov, D.S., 1993, M.: Nauka. (Humic substances in the biosphere. Ed. Orlov, D.S., 1993, M.: Nauka), 238 p. (in Russian).

IX. Grishina, L.A., 1986, Gumusoobrazovaniye i gumusnoye sostoyaniye pochv. M.: MGU (Grishina, L.A., 1986, Humus formation and humus state of soils, M.: Moscow State University, 242 p.). (in Russian).

X. Zvyagintsev, D.G., 1973, Vzaimodeystviye mikroorganizmov s tverdymi poverkhnostyami. M.: Izd. MGU ( Zvyagintsev, D.G., 1973, The interaction of microorganisms with solid surfaces. M.: Moscow State University), 176 p. (in Russian).

XI. Shannon, C. , 1963, Works on Information Theory and Cybernetics, Moscow.

XII. Kolmogorov, A.N., 1987, Information Theory and Theory of Algorithms. Nauka. Moscow. (in Russian).

XIII. Kovda, V., 1985, Biogeokhimiya pochvennogo pokrova, M.: Nauka (Kovda,V., 1985, Biogeochemistry of soil cover. M.: Science), 312 p. (in Russian).

XIV. Anikina,L., and Mukhomorov,V., 2015, The dynamic Relations Between the Content of Chemical Elements in the Roots and Reproductive Organs of Plants under Conditions of Primary Soil Formation, Agrofizika (Agrophysics), No.1(Jan. 2015), 26-34. (in Russian).

XV. Ermakov,E., Anikina, L., and Mukhomorov, V., 2006, Sbornik nauchnykh trudov po ovoshchevodstvu i sadovodstvu. K 75-letiyu Vserossiyskogo NII ovoshchevodstva. Tekhnologiya i zemledeliye. Vol. 2. (Collection of scientific papers on vegetable growing and gardening. On the 75th anniversary of the Russian Research Institute of vegetable growing. Technology and Agriculture, Vol. 2. Moscow.) (in Russian). 
ISSN $2393-9257$

Volume 3 Number 2

Journal of Advances in Natural Sciences

XVI. Mukhomorov, V., and Anikina, L., 2011, Information Flows between Organic Matter of the Root Environment and Elemental Chemical Composition of Plants under Primary Pedogenic Conditions, Russian Agricultural Sciences, 37(Aug. 2011), 322-326. 